\title{
Geographic Distribution Shift of Invasive Plant Austroeupatorium inulifolium in the Future Climate Projection
}

\author{
Angga Yudaputra ${ }^{1^{*}}$, Izu Andry Fijridiyanto ${ }^{1}$, Inggit Puji Astuti ${ }^{1}$ \\ Rizmoon Nurul Zulkarnaen ${ }^{1}$, Ade Yuswandi ${ }^{1}$, Joko R. Witono ${ }^{1}$ and Yuzammi $^{1}$ \\ ${ }^{1}$ Center for Plant Conservation and Botanic Gardens, Indonesian Institute of Sciences (LIPI). JI. Ir. H. \\ Djuanda No.13, Paledang, Bogor 16211, West Java, Indonesia.
}

\begin{abstract}
Authors' contributions
This work was carried out in collaboration among all authors. Author AY designed the study, performed the statistical analysis, wrote the protocol, and wrote the first draft of the manuscript. Authors IAF, IPA and RNZ managed the analyses of the study and wrote the first draft of the manuscript. Author AY prepared the spatial data. Authors JRW and Y managed the literature searches and wrote the first draft of the manuscript. All authors read and approved the final

manuscript.

Article Information

DOI: $10.9734 / A R R B / 2021 /$ v36i530373

Editor(s):

(1) Dr. Msafiri Yusuph Mkonda, Sokoine University of Agriculture, Tanzania. Reviewers:

(1) Sidney Augusto Vieira Filho, Farmácia. Universidade Federal de Ouro Preto. Ouro Preto, Brazil.

(2) Rafael Luiz Frinhani Rocha Núcleo de, Universidade Estadual do Norte Fluminense, Brasil. Complete Peer review History: http://www.sdiarticle4.com/review-history/68482
\end{abstract}

Original Research Article

Received 20 March 2021

Accepted 28 May 2021

Published 29 May 2021

ABSTRACT

Aims: This study aims to predict the future geographic distribution shift of invasive plant species Austroeupathorium inulifolium as the impact of global climate change.

Study Design: The rising temperature and precipitation change lead to the geographic distribution shift of organisms. A. inulifolium belongs to invasive plant species that often causes a substantial economic loss and ecological degradation in the invaded areas. Modelling of species distribution using the climate-based model could be used to understand the geographic distribution shift of invasive species in the future scenario under global climate change.

Place and Duration of Study: Center for Plant Conservation and Botanic Gardens - LIPI and 6 months.

Methodology: The total 2228 of occurrence records were derived from the Global Biodiversity 
Information Facility (GBIF) database. The seven climatic variables were selected from 19 variables using a pairwise correlation test (vifcor) with a threshold $>0.7$. The ensemble model was used by combining Random Forest (RF) and Support Vector Machine (SVM).

Results: Both two models are well-performed either using AUC or TSS evaluation methods. RF and SVM have AUC >0.95, and TSS $>0.8$. The predicted current distribution tends to have larger distribution areas compared to observed occurrence records. The predicted future distribution seems to be shifted in several parts of North America and Europe.

Conclusion: The geographic distribution of invasive plant species $A$. inulifolium will be shifted to the Northern part of globe in 2090. Mean temperature of driest quarter and precipitation of warmest quarter are the two most important variables that determine the distribution pattern of the $A$. inulifolium. The predictive distribution pattern of invasive plant $A$. inulifolium would be important to provide information about the impact of climate change to the geographic distribution shift of this species.

Keywords: Species distribution modeling; ensemble Model; invasive plant species; austroeupathorium inulifolium; climate change.

\section{INTRODUCTION}

The invasive plant species often cause bad impacts on the environment, such as habitat degradation, ecosystem disruption, vegetation composition change, and growth suppression of native plants. Austroeupatorium inulifolium (Kunth) R.M. King \& H.Rob. is known as salvia amarga that belongs to one of invasive plants and listed as agricultural and environmental weeds. It causes serious problems by invading many agricultural plantations, such as tea, rubber, rosella, and rice and dominates secondary forests [1]. It is a native plant to Panama, South tropical America, and Trinidad [POWO 2021]. It is also introduced in Indonesia [2]. It is herbaceous or shrub that can grow up to $5 \mathrm{~m}$ high. It can occupy a wide range of habitats such as savanna, swamp, forest border, disturbed areas, plantation and perennial crops, and roadsides [1].

According to the global distribution database, it is dominantly found in South America, Australia, Southeast Asia, and East Asia. The distribution of invasive species depends on many factors, mainly by climate factor. The surface temperature of the earth is increased around 0.9 ${ }^{\circ} \mathrm{C}$ since the late 19th century due to the increasing of carbon dioxide concentration and human-made emission into atmosphere [3]. Most of the warming is recorded in the past 35 years, with the warmest year is happened since [4]. The change of temperature and precipitation make the distribution shifts of the species may be inevitable [5]. The geographic range of species is evidently shifted in longitude and latitude due to their responses to changing regional climates [6].
It remains a challenge to predict the shift of species range under climate change and human anthropogenic (habitat destruction and land use change) [7].

It is important to identify the regions that have similar climatic condition where the species occurred and the areas that might be invaded on the future scenario due to climate change. Furthermore, the information about how the species responses to the climate alteration across the landscape would be useful in terms of management control. Currently, there are many species distribution modellings have been developed to investigate the impact of climate change to the distribution pattern of the plants. However, an effort for finding robust model to determine the distribution shift of invasive plants remains a challenge. The ensemble model combines several algorithms to predict a particular outcome [8]. Although the ensemble model is built from multiple base models within the model, it acts as a single model [9]. The advantages of using an ensemble model are to reduce the generalization error of the prediction, decrease the error of model prediction, and perform more accurate projection than the single model [10-11]. Previous study stated that ensemble model outperform in predicting the spatial distribution of Bornean Ironwood (Eusideroxylon zwageri) [12]. A single model is more likely not well suited to provide accurate future projection. The ensemble model is relatively more effective in prediction of range shift [13-14]. This study aims to predict future distribution of an invasive plant species $A$. inulifolium as the impact of climate change. 


\section{METHODOLOGY}

\subsection{Study Species}

Austroeupatorium inulifolium is an aggressive invasive species belongs to the Asteraceae [15]. It is native to Tropical South America and spreads to Southwest China, Indonesia (Java and Sumatra), Sri Lanka, and Taiwan [16]. It is a perennial plant, erect herb or shrub, and has a height up to $5 \mathrm{~m}$ (Fig 1a; 1b). Stem is rounded, covered with dense short hairs. Leaves are simple, ovate to narrowly oblong, 7-18 cm long, 2-8 cm wide, opposite in the lower part and sub opposite or alternate in the upper part. Inflorescences are corymbose panicles, arising from the end of branches or upper nodes. Flowers are white, bisexual, narrowly funnel form and ca. $4 \mathrm{~mm}$ long. Flowering period is between September and January. Fruits are achenes, elongate obconical, 5-ribbed and ca. $2 \mathrm{~mm}$ long. This species occurs at $100-2100 \mathrm{~m}$ altitude in many type of habitats, such as savannas, swamps, disturbed forests, plantations and perennial crops, fallow fields, waste lands and roadsides [15], [17].

\subsection{Data Mining}

All the occurrence records of $A$. inulifolium was extracted from the GBIF global database [19]. The 2230 presence points were recorded from all countries around the globe. All climatic variables that are provided by global climate data were downloaded [20]. These climatic variables were then selected using multicollinearity test [21]. The "usdm" threshold 0.7 was used to eliminate strong correlation among climate variables [22]. These selected climatic variables were then used as predictors of the model. All climatic variables were available with resolution 2.5 arc minutes (5 $\mathrm{km})$. The future climatic scenario in 2090 was used as input to predict future distribution. The worst climate scenario with RCP 8.5 was used to understand how the distribution will shift in the future due to climate change.

The ensemble model was used by combining multiple models, namely Random Forest (RF) and Support Vector Machine (SVM). These models were chosen because some previous study stated these models produced good results in model evaluation [23]. Furthermore, RF produced high accuracy model in forecasting the spatial distribution of invasive plant across landscape of Bali [24]. The "rgbif" package was used to load the occurrence records on the $R$ programming [25]. We used both presence and absence (e.g. pseudo-absence) data records. The pseudo-absence data about 1000 points were randomly selected using those algorithms. We used "sdm" package to run the model distribution [26]. The outputs of the analysis were predicted current potential distribution, predicted future potential distribution, predicting map of geographic change, and the importance variables that affecting the distribution of $A$. inulifolium. Topography, soils and other parameters (dispersal, biotic interaction, land use change) were excluded in this model.

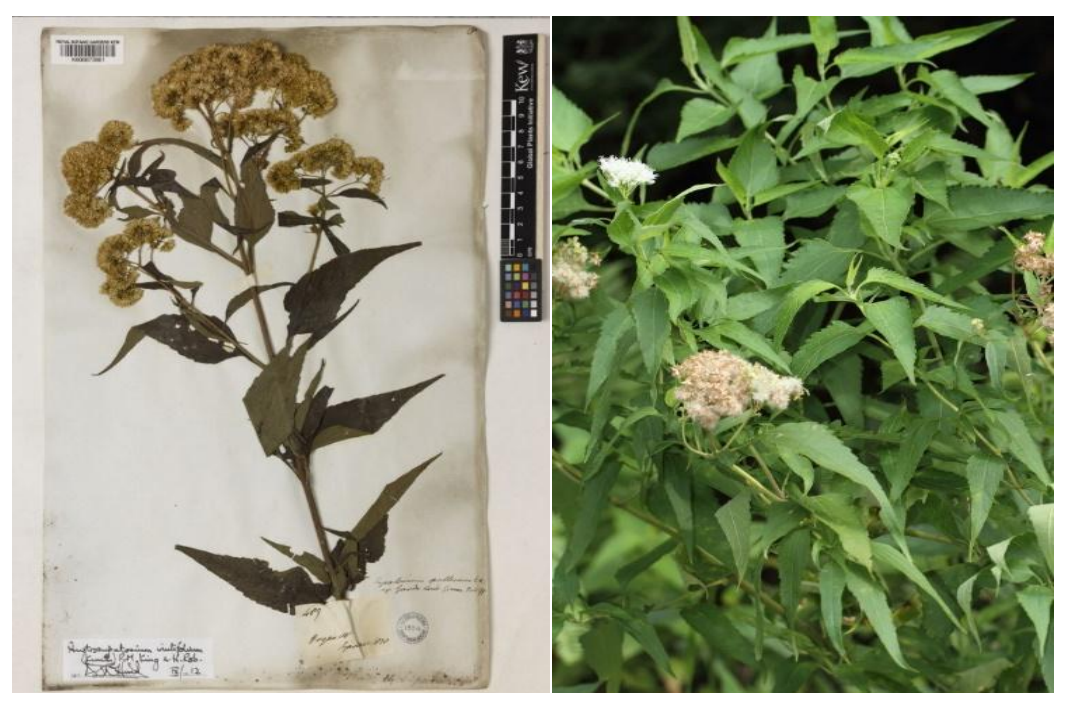

Fig. 1. Austroeupatorium inulifolium. a. Herbarium specimen, b. Living specimen [18] 


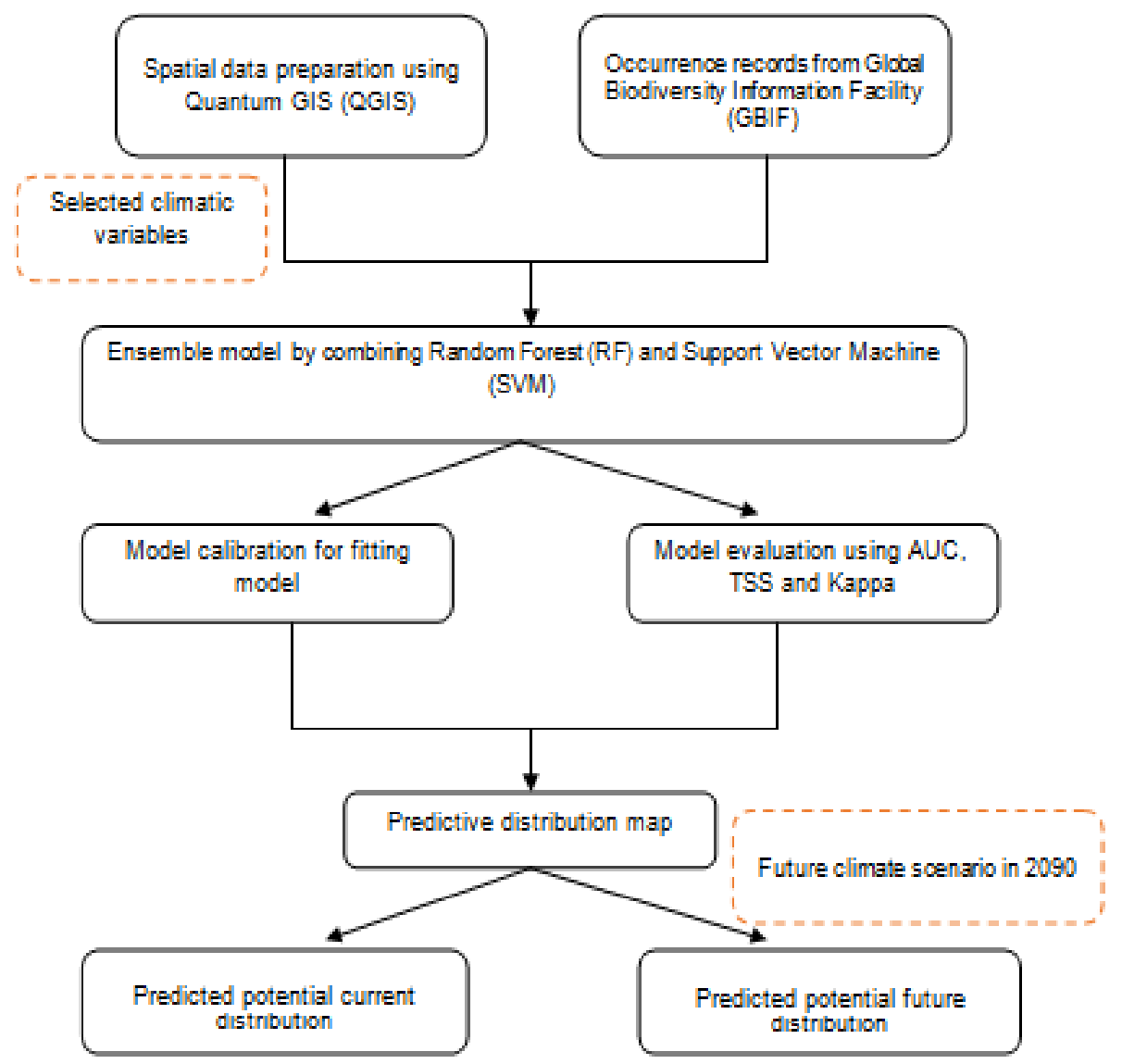

Fig. 2. Schematic diagram of species distribution modelling that used in predicting the distribution of $A$. inulifolium. AUC $=$ area under the curve, TSS $=$ True Skill Statistic and Kappa $=$ coefficient $(\mathrm{K})$

\section{RESULTS AND DISCUSSION}

Seven climatic variables are selected from 19 climatic variables through a stepwise procedure. The test aims to know the multicollinearity problem when fitting the model. It excludes the strong correlated climatic variables. Multicollinearity problems arise in which the model has many predictors that are not independent of each other. It leads to biased estimation [27] and reduces the precision of the estimated coefficient [28]. The default threshold on the pairwise correlation provided by 'usdm' package was 0.9 , but we use a threshold $>0.7$ and drop the highly correlated variables. The threshold between 0.7 and 0.9 can be used in multicollinearity test, but the threshold affects the number of selected variables in the fitting model. Both predictive models (RF and SVM) show AUC value $>0.90$ and TSS $>0.80$. The AUC and TSS are important evaluation metrics for checking any classification model's performance. These are capable of distinguishing between two classes (present and absent). RF and SVM are categorized to excellent predictive models in predicting the distribution of this species. Higher AUC and TSS, the better model distinguishing between the presence and absence of species. The RF and SVM characterize the region where the $A$. inulifolium is present in every grid cell. Each grid cell contains 7 specific climatic variables overlaid on it. These algorithms try to classify those climatic variables in all occurrence records of species. The model also uses the pseudo-absence that is randomly collected in regions where this species is probably absent. After working on classifying and analyzing the all selected climatic variables both in presence and pseudo-absence points, the algorithm then predicts the other regions across the landscape that have a similar climatic condition in the area where this species is present and absent based 
on the occurrence data. The value from 0-1 represents the predicted distribution areas. The yellow to green color represents the predicted geographic distribution areas that most suitable for this species. It means those regions are highly predicted as geographic distribution of this species. Conversely, the red to white color indicates the predicted geographic regions that less suitable for this species.

According to the recorded database, $A$. inulifolium is known to have widespread areas throughout the world. It is found in South America (Brazil, Paraguay, Uruguay, Chile, Bolivia, Peru, Ecuador, Colombia, Panama) and Southeast Asia (Indonesia and Timor Leste). Based on the occurrence records, it indicates that this species prefers to occupy in warmer areas (tropical areas) (Fig. 3). The predictive map of potential current distribution demonstrates that the suitable geographic regions of this species are predicted in South America (Brazil, Paraguay, Uruguay, Chile, Bolivia, Peru, Ecuador, Colombia, Panama,
Belize, Nicaragua, Mexico), Southern part of United States, Africa (Congo, Kenya, Cameroon, Tanzania, Togo, Liberia, South Africa, and Mauritius), Europe (France, Italia, Slovakia, Belgium), South Asia (Pakistan, Nepal, Small part of India, Sri Langka), Southeast Asia (Japan, Taiwan, Philippines, New Guinea, Thailand, Brunei, Malaysia, Indonesia), Australia, New Zealand, Fiji, and Vanuatu (Fig. 5). The predicted current distribution tends to have a wide of distribution areas compared to observed presence records. It is probably caused the prediction models only use the climatic variables as input, it makes potential current distribution covers a huge area in the globe. There are many variables that probably affect the distribution, but we exclude those and focus on the climate only. The previous studies stated that this invasive species occurred in Taiwan [15] and Sri Lanka [29] Those two countries are similar to the result of predictive map of current potential distribution. It seems that the predictive map is relatively good in predicting the distribution of invasive species $A$. inulifolium.

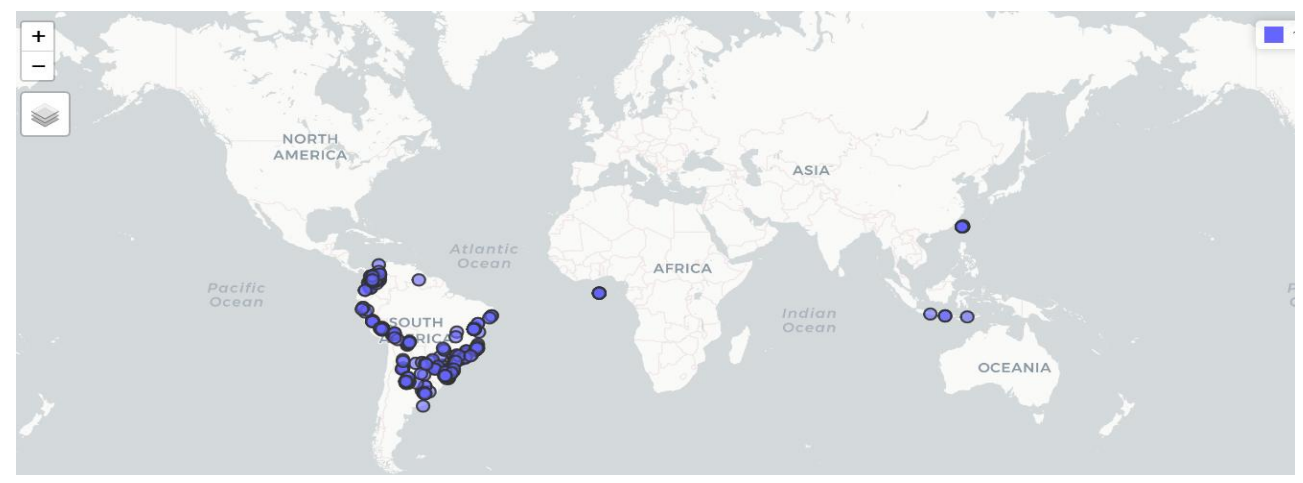

Fig. 3. The occurrence records of $A$. inulifolium extracted from GBIF database [19]. The "mapview" package in $\mathrm{R}$ was used to produce the map of occurrence points across the globe

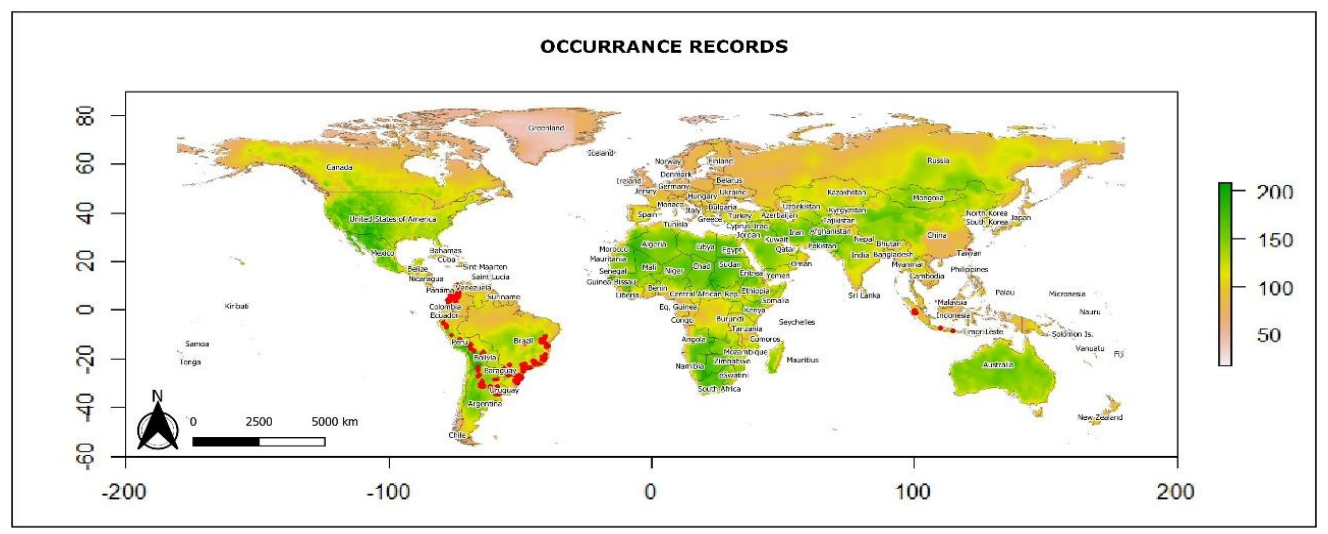

Fig. 4. The occurrence records were overlaid to the world climatic variable 


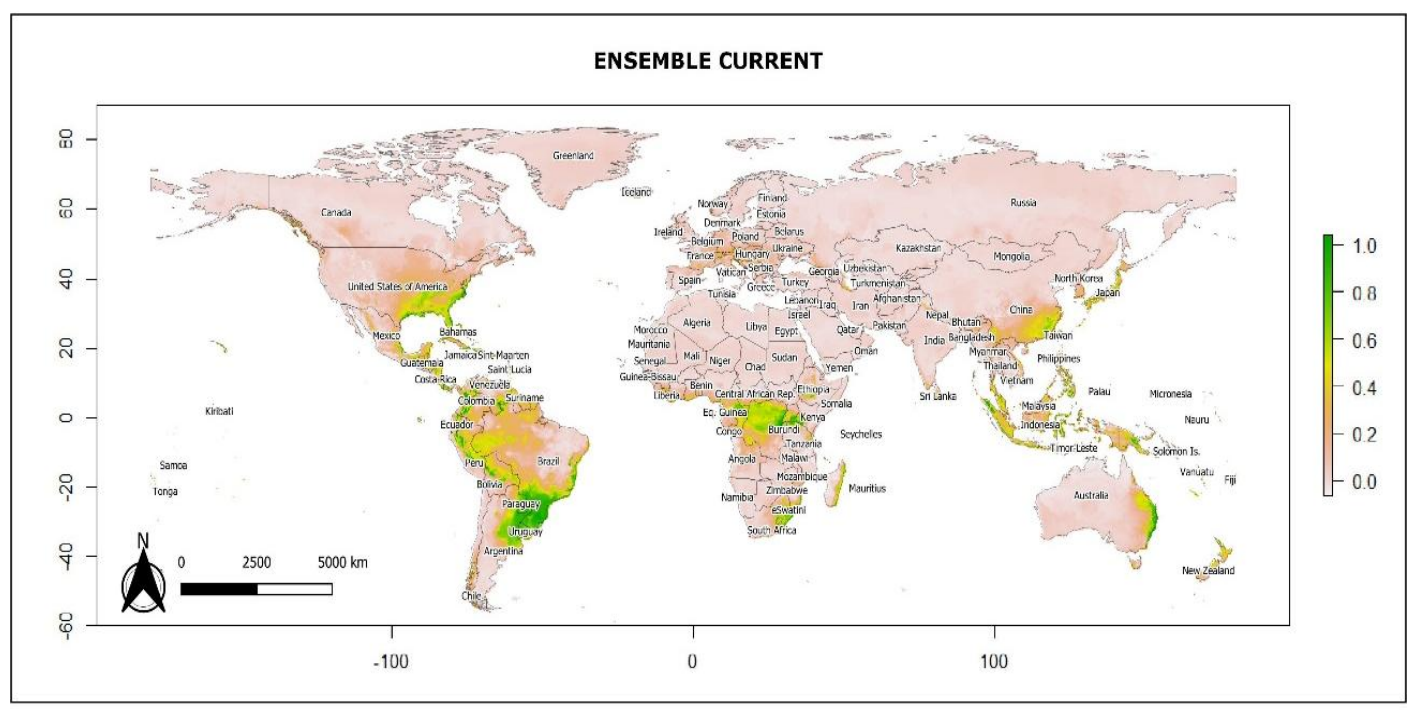

Fig. 5. The predictive map of potential current distribution provided by ensemble model prediction

The predictive map of potential future distribution in 2090 with the worst case scenario of global warming (RCP 8.5) shows that the geographic distribution tends to shift in different regions across the globe compared to predictive current distribution. The predictive future distribution map shows this species will expand its distribution to the Northern part of United States, Eastern part of Canada, North Europe (Norway and small part of Ireland), China and Japan (Fig. 6). The global annual temperature is arise at about $0.07^{\circ} \mathrm{C}$ $\left(0.13^{\circ} \mathrm{F}\right)$ per decade since 1880 and it becomes twice $\left(+0.18^{\circ} \mathrm{C} /+0.32^{\circ} \mathrm{F}\right)$ since 1981 [3][30]. The region in Northern globe tends to be warmer and it is suitable for this species to occupy and grow. The shifting geographic range might be caused by the change of precipitation and temperature that affect the species response. The invasive plant is relatively more adaptable with the environmental change. They probably adapt with the initial distribution region or probably occupy a new area and dominate the vegetation. The predicted distribution of $A$. inulifolium is predicted in the areas where $A$. inulifolium has not previously been found such as in Northern America. This phenomenon indicates that the tropics may become warmer, so the distribution of $A$. inulifolium shifted to the regions in the North of the Equator (Northern Hemisphere).

Based on climate based model, some regions may decrease their suitability for this invasive species. Those regions are South America,
Africa, Indonesia, and Australia (Fig. 8). However, this species may still occupy these regions because the invasive species tends to tolerant and adaptable to the environmental change. Whereas, the suitability increases in some regions in Northern Hemisphere. According to the predictive map in above, the regions that have a suitability increase for this species are seen in South America (Chile and Falkland Island), Northern part of United States, Canada, Europe (France, Belgium), East Asia (China, Japan), Southern part of Australia, and New Zealand (Fig. 8).

Both two algorithms also produce the important variables that affect the distribution pattern of this species. It turns out, mean temperature of driest quarter and precipitation of warmest quarter are the two most importance variables in shaping of the distribution pattern (Fig. 9). Selecting the variables or parameters on the modelling is a crucial step in terms of creating a model prediction. Some less important variables may make some noises of prediction and decrease the accuracy of the model. The suggestions regarding the predictor selection from an expert on the field of research object will be quite useful. The response curve illustrates how the species response to the environmental change or gradient (Fig. 10). We could mark the curve that extremely changes from flat goes to steep, indicating the variables that very important in affecting the distribution of this species. 


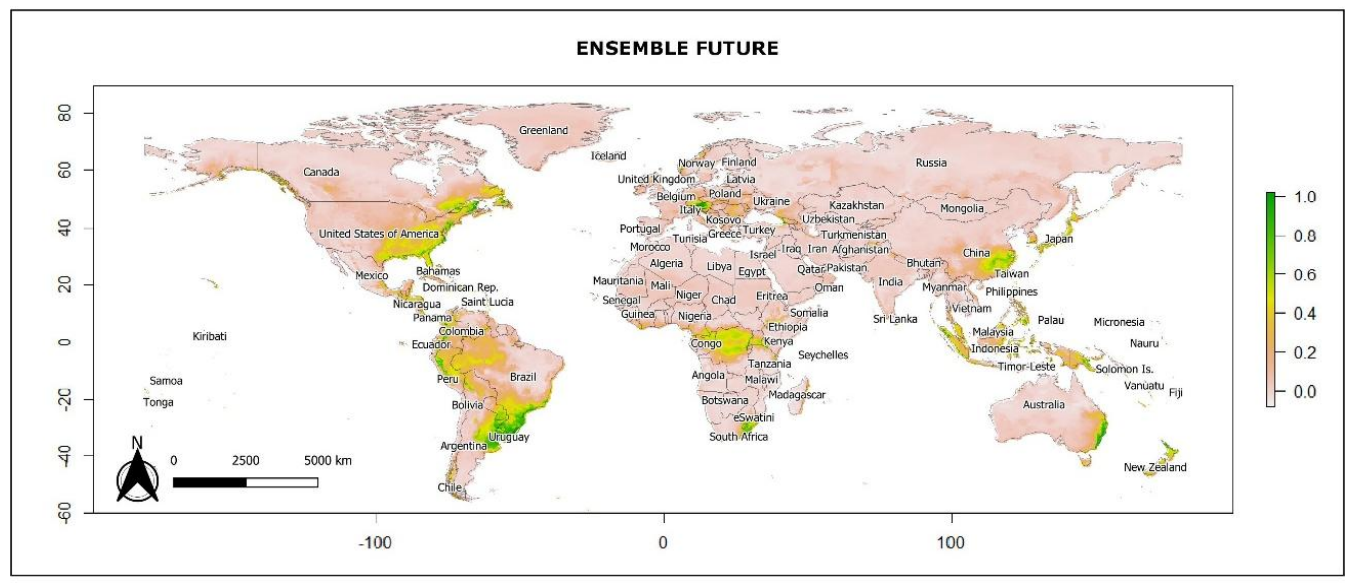

Fig 6. The predictive map of potential future distribution provided by ensemble model prediction

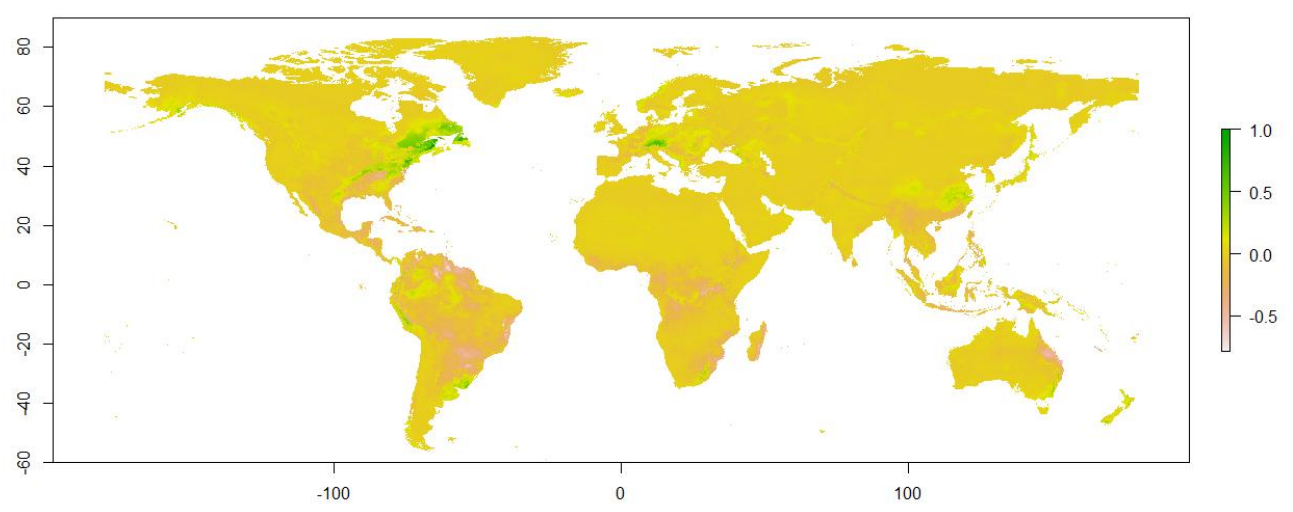

Fig. 7. The change of the distribution of $A$. inulifolium by subtracting the predicted future distribution areas to the current distribution areas

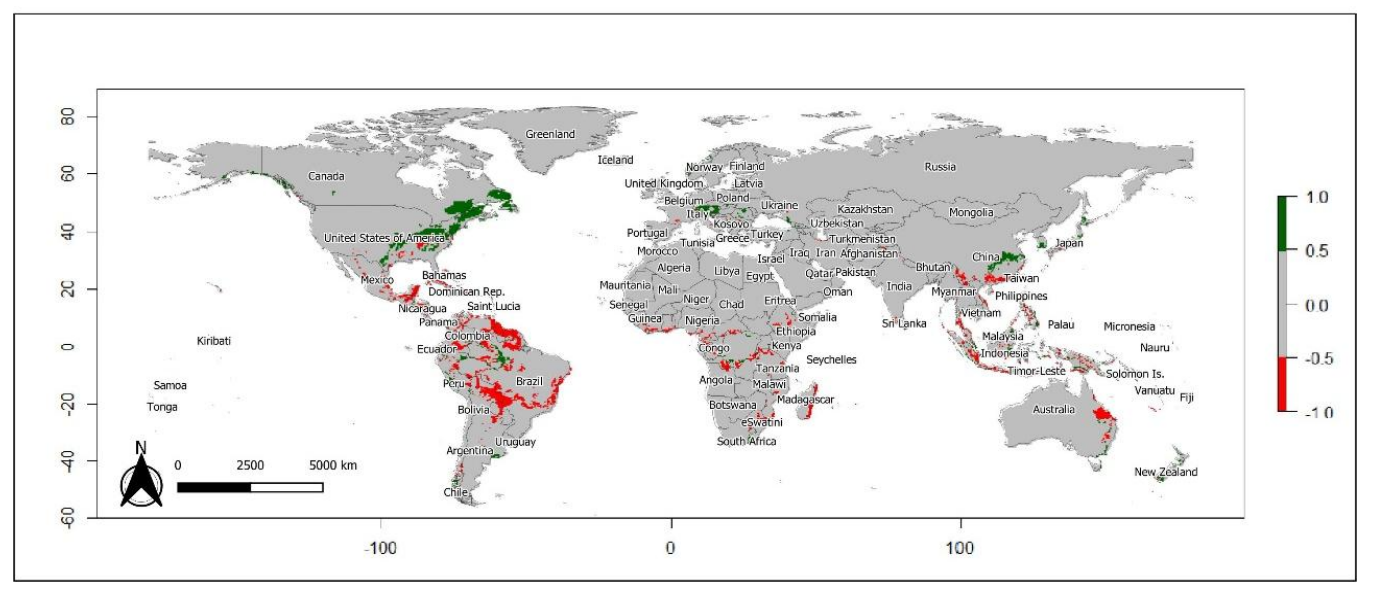

Fig. 8. The predictive map of potential future distribution. The map consists of two different color, the red color represents the geographic distribution with suitability decrease and the green color represents the geographic distribution with suitability increase due to climate change 


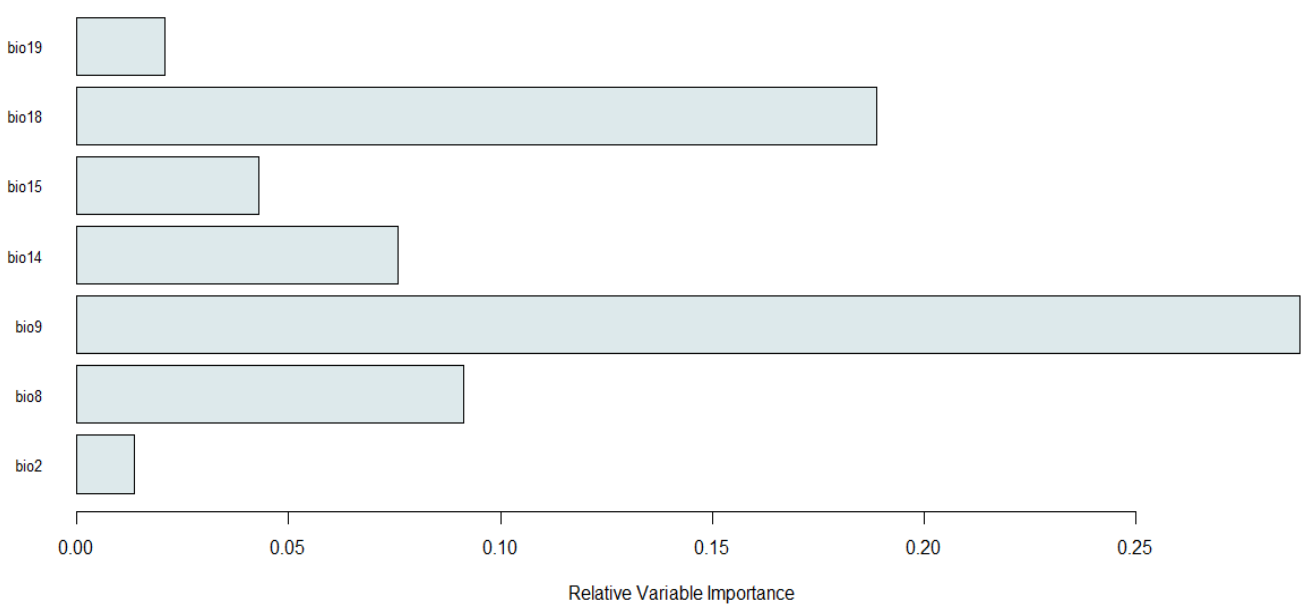

Fig. 9. The importance variables that determine the geographic distribution of $A$. inulifolium

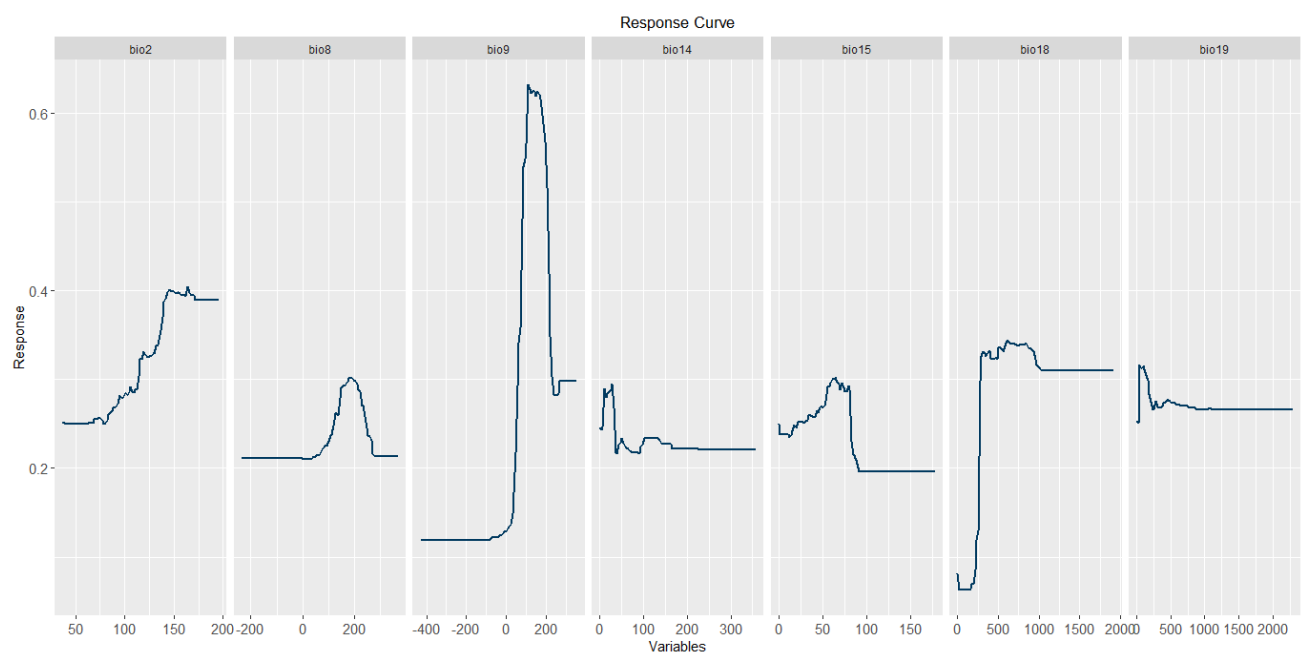

Fig. 10. Response curve of this species to the seven selected climatic variables

\section{CONCLUSION}

The geographic distribution of invasive species A. inulifolium will be shifted to the Northern Hemisphere in 2090. Mean temperature of driest quarter and precipitation of warmest quarter are considered as the most two important factors that affecting the distribution of $A$. inulifolium.

\section{ACKNOWLEDGEMENTS}

We thank to the Director of Research Center for Plant Conservation and Botanic Gardens who gives us a permit to conduct this research. Our great thanks also deliver a Coordinator of Research Division who provides a facility to accomplish this work.

\section{COMPETING INTERESTS}

Authors have declared that no competing interests exist.

\section{REFERENCES}

1. GIS. Database, Species profile: Austroeupatorium inulifolium; 2020. [Online].

Available:http://www.iucngisd.org/gisd/spe ciesname/Austroeupatorium+inulifolium.

2. K. Robert M, The genera of Eupatorieae (Asteraceae). Monographs in Systematic. 1987;22.

3. NOAA. State of the Climate: National Climate Report for Annual; 2019-2020. 
4. Potter S, Cabbage M, McCarthy L. NASA, NOAA data show 2016 warmest year on record globally," NASA Climate Change; 2017.

5. Lynch M, Lande R. Evolution and extinction in response to environmental change," Biot. Interact. Glob. Chang; 1993.

6. Parmesan C, Yohe G. "A globally coherent fingerprint of climate change impacts across natural systems," Nature; 2003.

DOI: $10.1038 /$ nature01286.

7. Lenoir J, et al. "Going against the flow: Potential mechanisms for unexpected downslope range shifts in a warming climate," Ecography (Cop.); 2010.

DOI: 10.1111/j.1600-0587.2010.06279.x

8. Araújo $M B, M$. New, Ensemble forecasting of species distributions," Trends in Ecology and Evolution; 2007.

DOI: 10.1016/j.tree.2006.09.010.

9. Kotu V, Deshpande B, Kotu V, Deshpande B. "Chapter 2 - Data Mining Process," in Predictive Analytics and Data Mining; 2015.

10. Marmion $\mathrm{M}$, Parviainen $\mathrm{M}$, Luoto $\mathrm{M}$, Heikkinen RK, Thuiller W. "Evaluation of consensus methods in predictive species distribution modelling," Diversity Distribution; 2009.

DOI: 10.1111/j.1472-4642.2008.00491.x.

11. Grenouillet G, Buisson L, Casajus N, Lek S. Ensemble modelling of species distribution: The effects of geographical and environmental ranges, Ecography (Cop.); 2011.

DOI: 10.1111/j.1600-0587.2010.06152.x.

12. Yudaputra A, Fijridiyanto IZU, Cropper WP. The potential impact of climate change on the distribution pattern of eusideroxylon zwageri (Bornean ironwood) in Kalimantan, Indonesia," Biodiversitas; 2020.

DOI: $10.13057 /$ biodiv/d210140.

13. Thuiller W. Patterns and uncertainties of species' range shifts under climate change," Glob. Chang. Biol; 2004. DOI: 10.1111/j.1365-2486.2004.00859.x.

14. Araújo MB, Whittaker RJ, Ladle RJ, Erhard $M$. Reducing uncertainty in projections of extinction risk from climate change," Glob. Ecol. Biogeogr; 2005.

DOI: 10.1111/j.1466-822X.2005.00182.x.

15. Hsu T, Peng C, Wang C. Austroeupatorium inulifolium ( Kunth ) King \& Robinson (Asteraceae ), a Newly Naturalized Plant in Taiwan," Phytologia. 2006;51(1):41-45.
16. King $H$, Robinson $R M$. Studies in the Eupatorieae (Compositae)--- XXVI. A new genus Austroeupatorium," in Phytologia. 1970;433-434.

17. HJ, BR. Leanne Brown, Northern Australia Quarantine Strategy: Weeds Target List; 2008.

18. King RM, Rob $\mathrm{H}$, Austroeupatorium inulifolium; 2021.

Available:

http://www.plantsoftheworldonline.org/taxo n/urn:Isid:ipni.org:names:27149-2.

19. GBIF.org, GBIF Occurrence; 2021.

Available: https://doi.org/10.15468/dl.js2by6

20. Hijmans RJ, Cameron SE, Parra JL, Jones $P G$, Jarvis A. "Very high resolution interpolated climate surfaces for global land areas," Int. J. Climatol; 2005.

DOI: 10.1002/joc.1276.

21. Naimi B, Hamm NAS, Groen TA, Skidmore AK, Toxopeus AG. "Where is positional uncertainty a problem for species distribution modelling?," Ecography (Cop.); 2014.

DOI: 10.1111/j.1600-0587.2013.00205.x.

22. Naimi B. Package 'usdm'. Uncertainty Analysis for Species Distribution Models, R- Cran; 2017.

23. Yudaputra A, Pujiastuti I, Cropper WP. Comparing six different species distribution models with several subsets of environmental variables: Predicting the potential current distribution of Guettarda speciosa in Indonesia," Biodiversitas; 2019.

DOI: $10.13057 /$ biodiv/d200830.

24. Yudaputra A. Modelling potential current distribution and future dispersal of an invasive species calliandra calothyrsus in Bali Island, Indonesia," Biodiversitas; 2020. DOI: $10.13057 /$ biodiv/d210233.

25. Chamberlain S. Package 'rgbif' - Interface to the Global 'Biodiversity' Information Facility API," CRAN Repository; 2019.

26. Naimi B, Araújo MB. "Sdm: A reproducible and extensible $\mathrm{R}$ platform for species distribution modelling," Ecography (Cop.); 2016.

DOI: 10.1111/ecog.01881.

27. Yoo W, Mayberry R, Bae S, Singh K, Peter He Q, Lillard JW. "A Study of Effects of MultiCollinearity in the Multivariable Analysis.," Int. J. Appl. Sci. Technol; 2014.

28. Tu YK, Kellett M, Clerehugh V, Gilthorpe MS. "Problems of correlations between explanatory variables in multiple 
regression analyses in the dental literature," British Dental Journal; 2005. DOI: $10.1038 /$ sj.bdj.4812743.

29. Pethiyagoda RS, Nanayakkara S. "Invasion by Austroeupatorium inulifolium (Asteraceae) arrests succession following tea cultivation in the highlands of Sri Lanka," Ceylon J. Sci. (Biological Sci; 2012.

DOI: $10.4038 /$ cjsbs.v40i2.3934.

30. NOAA, Climate Prediction Center, National Weather Service; 2018.

(c) 2021 Yudaputra et al.; This is an Open Access article distributed under the terms of the Creative Commons Attribution License (http://creativecommons.org/licenses/by/4.0), which permits unrestricted use, distribution, and reproduction in any medium, provided the original work is properly cited.

Peer-review history:

The peer review history for this paper can be accessed here: http://www.sdiarticle4.com/review-history/68482 